\title{
Parent-child cooking meal together may relate to parental concerns about the diets of their toddlers and preschoolers: a cross- sectional analysis in Japan
}

Midori Ishikawa ${ }^{1 *} \mathbb{D}$, Kumi Eto ${ }^{2}$, Miki Miyoshi $^{3}$, Tetsuji Yokoyama', Mayu Haraikawa ${ }^{4}$ and Nobuo Yoshiike ${ }^{3}$

\begin{abstract}
Background: Parents often have concerns about the food habits of their young children. Cooking is a frequent behavior related to dietary activities at home. We hypothesized that "a parent cooking meals together with young children might alleviate dietary concerns." The aim of this study was to identify the relationship between parental cooking practices (e.g., cooking meals together with the child) and diet-related concerns.

Methods: Data were extracted from the "National nutrition survey on preschool children" conducted among nation-wide households with toddlers and preschoolers in 2015 by the Ministry of Health, Labour and Welfare of Japan. Parents were classified into two groups comprising those who cooked meals together with their children and those who did not. The following variables were compared: taking too much time to eat (slow eaters), "picky" eating (eating only certain foods), inconsistent food intake (eating too much or too little), playing with food/utensils while eating, preferring sweetened beverages and snacks over meals, eating too fast to chew well, not swallowing food, disinterested in eating, and spitting out food. The associations between parent-child cooking meals together and the concerns pertaining to the child's dietary habits and food intake were analyzed and compared between the two groups.
\end{abstract}

Results: The concerns of "picky eating" and "playing with food/utensils while eating" were lower, while "eating too much" was higher in the parent-cooking together group. The intake frequency of fish, soybeans/soy products, vegetables, and milk among children were higher in the "cooking together" group than among those in the "not cooking together" group. Children in the "cooking together" group consumed a significantly greater variety of foods than those in the "not cooking together" group.

Conclusions: Cooking a meal together with a child may be related to the parent's lower concerns about the dietary habits of the child, including "picky eating" and "playing with food/utensils while eating," but may also be related to the higher concerns of "eating too much."

Keywords: Cooking together, Child, Parent, Picky eating, Playing with food/utensils while eating, Eating too much

\footnotetext{
*Correspondence: ishikawa.m.aa@niph.go.jp

${ }^{1}$ Department of Health Promotion, National Institute of Public Health, 2-3-6

Minami, Wako, Saitama 351-0197, Japan

Full list of author information is available at the end of the article
}

(c) The Author(s). 2019 Open Access This article is distributed under the terms of the Creative Commons Attribution 4.0 International License (http://creativecommons.org/licenses/by/4.0/), which permits unrestricted use, distribution, and reproduction in any medium, provided you give appropriate credit to the original author(s) and the source, provide a link to the Creative Commons license, and indicate if changes were made. The Creative Commons Public Domain Dedication waiver (http://creativecommons.org/publicdomain/zero/1.0/) applies to the data made available in this article, unless otherwise stated. 


\section{Background}

Dietary intake and eating habits developed in early childhood affect the development of school-aged children [1]. Furthermore, eating behaviors affect health and nutritional status in adulthood, and the onset of lifestylerelated diseases [2-4].

According to the "National nutrition survey on preschool children" conducted in Japan [5], about $80 \%$ of parents expressed frequent concerns about the dietary habits of their children, such as "taking too much time to eat," "picky eating (eating only certain foods)," "inconsistent food intake (eating too much or too little, depending on the day,") "playing with food/utensils while eating," "preferring sweetened beverages and snacks over meals," and "eating too fast to chew well."

There have been several reports on how parents can alleviate dietary-related concerns in school-aged children. Some claim that cooking a meal together with others in school or preschool is an effective way to improve "picky eating," "eating too fast," and "preferring sweetened beverages and snacks over meals" [6-8].

Another study reported that the dislike of vegetables and picky eating had improved with classes and practical sessions, including lessons in the school curriculum on cooking meals, as well as food and nutrition (shokuiku in Japanese) [9]. Even in early childhood, some nursery schools and kindergartens have incorporated parentchild cooking classes in shokuiku programs, and reported that this strategy can effectively improve a child's dislike of vegetables $[9,10]$.

However, the formation of dietary behaviors in the preschool period might be related to the dietary habits of the parents [11-15]. Cooking is a repeated behavior related to dietary practices at home and some parents may cook a meal together with a young child. Nevertheless, relatively few studies have investigated the influence of parent-child cooking activities at home on the dietary behaviors of children and whether such activities may relate to parental concerns regarding the dietary habits of young children [6].

We hypothesized that "a parent cooking meals together with a young child" may relate to parental concerns about the dietary habits of their children, such as "taking too much time to eat," "eating only certain foods," "eating inconsistent amounts of food," "playing with food/utensils while eating," "preferring sweetened beverages and snacks over meals," and "eating too fast to chew well" as well as "inconsistent food intake."

\section{Methods}

\section{Study population and procedure}

Data were retrieved from the "National nutrition survey on preschool children," which was conducted in September 2015 by the Ministry of Health, Labour, and Welfare,
Japan (MHLW) [5]. Children aged $\leq 6$ years as of May 31, 2015 were randomly selected from households in Japan among 1106 districts for the "Comprehensive Survey of Living Conditions." The three districts affected by heavy rain in September 2015 were excluded from the survey sampling. First, the MHLW explained the survey method to the prefectures. Subsequently, the prefectural public health center employed investigators to visit the households selected for this survey. The investigators asked the child's mother (or the caregiver involved in providing meals to the child) to complete a questionnaire, which was collected at a later date. In total, 2992 households with 3936 children aged $\leq 6$ years participated in the survey. The questionnaires of 65 children were excluded because information on age was not available. Finally, 3871 questionnaires were collected for analysis [5]. A database was prepared by the Maternal and Child Health Division, Department of Equal Employment and Children's Family, MHLW.

The "National nutrition survey on preschool children" has two types of questionnaires: one for infants aged $<2$ years and the other for children aged 2-6 years. Data obtained from the latter questionnaire were used in this study. In total, 2237 persons responded to all items consistent with the purpose of this study (Additional file 1).

\section{Measurement}

The objective variable of this study, parent-child cooking meals together, was posed as a question to the participants: "Do you (parent) try to cook a meal together with your child?" The parent answered with a "yes" or "no." Explanatory variables related to parents included relationships with the children, age of mother, current employment status of mother, structure of family members living together, subjective economic status, and leisure time (affluent, somewhat, neither, not so much, not at all) etc.

Parental concerns about the daily dietary habits of their children consisted of 11 items: "taking too much time to eat (slow eaters)," "picky" eating (eating only certain foods)," "the amount of inconsistent food intake (too much or too little, depending on the day)," "playing with food/utensils while eating," "preferring sweetened beverages and snacks over meals," "too little food intake, " "eating too fast to chew well," "not swallowing food," "disinterested in eating, "eating too much," and "spitting out food." For all questions, the parent answered with a "yes" or "no."

As for children, data of age, height, weight, nutritional status (degree of obesity), food allergies, tooth decay, and time spent on TV, video, and games were obtained. Furthermore, the food diversity score (FDS) was used to assess the nutritional quality of the whole diet [16]. The typical eating patterns of eight food groups (grains, fish, meat, eggs, soybeans/soy products, vegetables, fruit, and 
Table 1 Demographics of parent and household by the parent-child cooking together group

\begin{tabular}{|c|c|c|c|c|c|}
\hline & \multicolumn{2}{|c|}{ not cooking together } & \multicolumn{2}{|c|}{ cooking together } & \multirow[b]{3}{*}{$\mathrm{p}$} \\
\hline & $\bar{n}$ & $\%$ & $\bar{n}$ & $\%$ & \\
\hline & 2004 & 89.6 & 233 & 10.4 & \\
\hline \multicolumn{6}{|l|}{ Relationship for the child } \\
\hline mother & 1957 & 97.7 & 231 & 99.1 & 0.231 \\
\hline \multirow[t]{2}{*}{ father } & 47 & 2.4 & 2 & 0.9 & \\
\hline & mean & SD & mean & SD & $\mathrm{p}$ \\
\hline \multicolumn{6}{|l|}{ Age of mother (years old) $\dagger$} \\
\hline \multirow[t]{2}{*}{ mean, SD } & 36.0 & 5.1 & 35.4 & 5.5 & 0.101 \\
\hline & $\mathrm{n}$ & $\%$ & $n$ & $\%$ & $\mathrm{p}$ \\
\hline \multirow{2}{*}{\multicolumn{6}{|c|}{$\begin{array}{l}\text { Employment status of mother } \\
\text { currently work }\end{array}$}} \\
\hline & & & & & \\
\hline yes & 1135 & 56.6 & 132 & 56.7 & 0.996 \\
\hline no & 869 & 43.4 & 101 & 43.4 & \\
\hline \multicolumn{6}{|l|}{ Family living together } \\
\hline mother or father and one child & 75 & 3.7 & 14 & 6.0 & 0.365 \\
\hline mother or father and grandparent and one child & 64 & 3.2 & 7 & 3.0 & \\
\hline mother and father and one child & 314 & 15.7 & 44 & 18.9 & \\
\hline mother and father and children & 1209 & 60.3 & 128 & 54.9 & \\
\hline mother and father and grandparent and children & 339 & 16.9 & 40 & 17.2 & \\
\hline others (living together with non-family adults) & 3 & 0.2 & 0 & 0.0 & \\
\hline \multicolumn{6}{|l|}{ Subjective economic status } \\
\hline affluent & 155 & 7.7 & 26 & 11.2 & 0.357 \\
\hline somewhat & 423 & 21.1 & 42 & 18.0 & \\
\hline neither & 668 & 33.3 & 80 & 34.3 & \\
\hline not so much & 580 & 28.9 & 63 & 27.0 & \\
\hline no afford not at all & 178 & 8.9 & 22 & 9.4 & \\
\hline \multicolumn{6}{|l|}{ Leisure time } \\
\hline affluent & 144 & 7.2 & 36 & 15.5 & 0.0002 \\
\hline somewhat & 452 & 22.6 & 59 & 25.3 & \\
\hline neither & 459 & 22.9 & 42 & 18.0 & \\
\hline not so much & 746 & 37.2 & 74 & 31.8 & \\
\hline no afford not at all & 203 & 10.1 & 22 & 9.4 & \\
\hline \multicolumn{6}{|l|}{ Caregiver of the child during the day } \\
\hline \multicolumn{6}{|l|}{ Nursery school } \\
\hline yes & 827 & 41.3 & 98 & 42.1 & 0.816 \\
\hline no & 1177 & 58.7 & 135 & 57.9 & \\
\hline \multicolumn{6}{|l|}{ Kindergarten } \\
\hline yes & 747 & 37.3 & 91 & 39.1 & 0.595 \\
\hline no & 1257 & 62.7 & 142 & 90.9 & \\
\hline \multicolumn{6}{|l|}{ Centers for Early Childhood Education and Care } \\
\hline yes & 126 & 6.3 & 16 & 6.9 & 0.731 \\
\hline no & 1878 & 93.7 & 217 & 93.1 & \\
\hline
\end{tabular}


Table 1 Demographics of parent and household by the parent-child cooking together group (Continued)

\begin{tabular}{|c|c|c|c|c|c|}
\hline & \multicolumn{2}{|c|}{ not cooking together } & \multicolumn{2}{|c|}{ cooking together } & \multirow[b]{3}{*}{$\mathrm{p}$} \\
\hline & $n$ & $\%$ & $n$ & $\%$ & \\
\hline & 2004 & 89.6 & 233 & 10.4 & \\
\hline \multicolumn{6}{|l|}{ Grandparents and relatives } \\
\hline yes & 105 & 5.2 & 8 & 3.4 & \multirow[t]{2}{*}{0.234} \\
\hline no & 1899 & 94.8 & 205 & 96.6 & \\
\hline \multicolumn{6}{|l|}{ None of the above } \\
\hline yes & 248 & 12.4 & 29 & 12.5 & \multirow[t]{2}{*}{0.975} \\
\hline no & 1756 & 87.6 & 204 & 87.6 & \\
\hline \multicolumn{6}{|c|}{ Dietary lifestyle in mother/father } \\
\hline \multicolumn{6}{|l|}{ Eating breakfast } \\
\hline everyday & 1878 & 93.7 & 218 & 93.6 & \multirow[t]{5}{*}{0.423} \\
\hline 4-5 days per week & 100 & 5.0 & 15 & 6.4 & \\
\hline 2-3 days per week & 5 & 0.3 & 0 & 0.0 & \\
\hline 1 day or less per week & 20 & 1.0 & 0 & 0.0 & \\
\hline I do not eat at all & 1 & 0.1 & 0 & 0.0 & \\
\hline
\end{tabular}

p: $x^{2}$ test

t: $t$ test

milk) were evaluated. Moreover, the intake of processed foods was also examined, in which four items (sweetened beverages, confectioneries, instant noodles, and fast food) were investigated by inquiring how often the participants consumed foods in each group ( $\geq 2$ times per day, once a day, 4-6 days per week, 1-3 days per week, and less than once a week or rarely).

\section{Nutritional status of children}

The nutritional status of children was determined based on body weight and height. The degree of obesity (\%) was calculated using the following formula: self-reported body weight (g) - standard body weight (g) for height/standard body weight $(\mathrm{g})$ for height $\times 100$. The judgment criteria for the degree of obesity were "obese" $(\geq 30 \%)$, "overweight" (20-30\%), "tendency to be overweight" (15-20\%), "standard" ( 15 to $+15 \%)$, "tendency to be underweight": (less than $-15 \%$ to less than $-20 \%$ ), and "underweight" (less than $-20 \%)$. The standard body weight was calculated using the formula of standard body weight for height in Japanese children $[17,18]$. The formula does not consider age because the standard body weight for height curves were almost identical for children aged 1-6 years [19].

\section{Statistical analysis}

By classifying the parents into two groups, parents who cooked meals together with their children ("cooking together") and those who did not ("not cooking together"), the parents' sex, age of mother, and socioeconomic status as well as the sex, nutritional status, food allergies, tooth decay, and time spent on TV, video, and games of children were compared.
Next, the 11 concerns of parents on the dietary habits of their children were compared between the two groups. Multivariate analysis was performed for each of the 11 concerns using a logistic regression model, adjusted for the relationship with the child (mother or father), child's sex, employment status of mother (yes or no), and family members in the household (other children, grandparents, and others) (Model 1).

Additional multivariate analysis was performed for each of the 11 concerns using a logistic regression model, adjusted for the relationship with the child (mother or father), child's sex, employment status of mother (yes or no), family living together (other children, grandparents, and others), subjective economic status (affluent, somewhat, neither, not so much, or not able to afford at all), leisure time (affluent, somewhat, neither, not so much, not at all), and place where the child spends time during the day (nursery school, kindergarten, center for early childhood education and care, with grandparents, with relatives, staying at home) (Model 2).

Finally, the frequency of food intake between the two groups was compared. The FDS was the total number of eight food groups (grains, fish, meat, eggs, soybeans/soy products, vegetables, fruits, and milk) being consumed at least once a day, and the processed food score was the total number of four food items (sweetened beverages, confectioneries, instant noodles, and fast food) being consumed at least once a day [16]. The FDS and the processed food score were compared between the two groups [16]. The FDS was 1 point if once or more a day or 0 points if less than that. There were eight types of food, thus the maximum score was eight points. 
Similarly, the processed food score was calculated as a score of 1 point if at least once a day or 0 points if less than that. There were four types of food, so the maximum score was four points. All statistical analyses were performed using SAS software, version 9.2 (SAS Institute, Inc., Cary, NC, USA). A probability $(p)$ value of < 0.05 was considered statistically significant.

\section{Results}

Table 1 compares the characteristics of mother's age, employment status, family members living together, subjective economic status or leisure time, and the place where and how the child spends during the day between the two groups. The "cooking together" group had more leisure time than the "not cooking together" group $(p=0.0002)$. However, there were no significant differences in the other variables between the two groups.

Table 2 compares the characteristics of the child's age, sex, nutritional status, food allergies, tooth decay, and the time spent on TV, video, or games between the two groups. In the "cooking together" group, the proportions of children spending less than $2 \mathrm{~h}$ per day on TV, video, or games during the weekdays $(p=0.025)$ and weekends $(p=0.015)$ were higher than those in the "not cooking together" group.

Table 3 presents the proportions of the parental concerns about the child's dietary habits (11 items) for both

Table 2 Characteristics of the child's age, sex, nutritional status, food allergies, tooth decay, and the time spent on TV, video or games by the parent-child cooking together group

\begin{tabular}{|c|c|c|c|c|c|}
\hline & \multicolumn{2}{|c|}{ not cooking together } & \multicolumn{2}{|c|}{ cooking together } & \multirow[b]{3}{*}{$\mathrm{p}$} \\
\hline & \multicolumn{2}{|c|}{$n=2004$} & \multicolumn{2}{|l|}{$n=233$} & \\
\hline & mean & SD & mean & SD & \\
\hline \multicolumn{6}{|l|}{ Age $\dagger$} \\
\hline \multirow[t]{2}{*}{ years old } & 4.2 & 1.1 & 4.3 & 1.1 & 0.310 \\
\hline & $n$ & $\%$ & $n$ & $\%$ & $p$ \\
\hline \multicolumn{6}{|l|}{ Sex } \\
\hline male & 1062 & 52.9 & 96 & 41.2 & 0.001 \\
\hline female & 944 & 47.1 & 137 & 58.8 & \\
\hline \multicolumn{6}{|l|}{ Nutritional status } \\
\hline$+30 \% \leq$ (obesity) & 10 & 0.5 & 4 & 1.7 & 0.731 \\
\hline +30 to $20 \%$ (overweight) & 26 & 1.3 & 2 & 0.9 & \\
\hline +15 to $20 \%$ (overweight tendency) & 50 & 2.5 & 8 & 3.4 & \\
\hline-15 to+15\% (standard) & 1870 & 93.3 & 208 & 89.3 & \\
\hline-15 to $-20 \%$ (underweight tendency) & 36 & 1.8 & 4 & 1.7 & \\
\hline$\leq-20 \%$ (underweight) & 12 & 0.6 & 7 & 3.0 & \\
\hline \multicolumn{6}{|l|}{ Food allergy symptoms } \\
\hline yes & 319 & 15.9 & 42 & 18.0 & 0.408 \\
\hline no & 1685 & 84.1 & 191 & 82.0 & \\
\hline \multicolumn{6}{|l|}{ Tooth decay } \\
\hline yes & 384 & 19.2 & 36 & 15.6 & 0.186 \\
\hline no & 1619 & 80.8 & 195 & 84.4 & \\
\hline \multicolumn{6}{|l|}{ Time spent on TV, video or games } \\
\hline \multicolumn{6}{|l|}{ weekday } \\
\hline None & 25 & 1.3 & 6 & 2.6 & 0.025 \\
\hline$<2$ hours /day & 1512 & 75.5 & 188 & 80.7 & \\
\hline$\geq 2$ hours /day & 467 & 23.3 & 39 & 16.7 & \\
\hline \multicolumn{6}{|l|}{ weekend } \\
\hline None & 15 & 0.8 & 5 & 2.2 & 0.015 \\
\hline$<2$ hours /day & 1147 & 57.2 & 147 & 63.1 & \\
\hline$\geq 2$ hours /day & 842 & 42.0 & 81 & 34.8 & \\
\hline
\end{tabular}


Table 3 Parental concerns about the child's diet (11 items) by child-parent cooking a meal together group

\begin{tabular}{|c|c|c|c|c|c|c|c|c|c|}
\hline \multicolumn{3}{|c|}{ Parental concerns about the diets of the child } & \multicolumn{2}{|l|}{ total } & \multicolumn{2}{|c|}{ not cooking together } & \multicolumn{2}{|c|}{ cooking together } & \multirow[t]{3}{*}{$p$} \\
\hline & & & & \multirow{2}{*}{$\begin{array}{l}\% \\
100\end{array}$} & \multirow{2}{*}{$\begin{array}{l}n \\
2004\end{array}$} & \multirow{2}{*}{$\begin{array}{l}\% \\
89.6\end{array}$} & \multirow{2}{*}{$\begin{array}{l}n \\
233\end{array}$} & \multirow{2}{*}{$\begin{array}{l}\% \\
10.4\end{array}$} & \\
\hline & & & & & & & & & \\
\hline \multirow[t]{2}{*}{1} & \multirow[t]{2}{*}{ He/she takes too much time for eating (eats slowly). } & yes & 740 & 33.1 & 667 & 33.3 & 73 & 31.3 & 0.549 \\
\hline & & no & 1547 & 69.2 & 1387 & 66.7 & 160 & 68.7 & \\
\hline \multirow[t]{2}{*}{2} & \multirow[t]{2}{*}{ He/she is a picky eater (eating only certain foods). } & yes & 693 & 31.0 & 635 & 31.7 & 58 & 24.9 & 0.034 \\
\hline & & no & 1544 & 69.0 & 1369 & 68.3 & 175 & 75.1 & \\
\hline \multirow[t]{2}{*}{3} & \multirow{2}{*}{$\begin{array}{l}\text { The amount of food intake is inconsistent (too much or too little, } \\
\text { depending on the day). }\end{array}$} & yes & 559 & 25.0 & 503 & 25.1 & 56 & 24.0 & 0.722 \\
\hline & & no & 1678 & 75.0 & 1501 & 74.9 & 177 & 76.0 & \\
\hline \multirow[t]{2}{*}{4} & \multirow[t]{2}{*}{ He/she plays with food/utensils while eating. } & yes & 533 & 23.8 & 494 & 24.7 & 39 & 16.7 & 0.007 \\
\hline & & no & 1704 & 76.2 & 1510 & 75.4 & 194 & 83.3 & \\
\hline \multirow[t]{2}{*}{5} & \multirow[t]{2}{*}{ He/she desires sweetened beverage or sweets more than a meal. } & yes & 408 & 18.2 & 369 & 18.4 & 39 & 16.7 & 0.531 \\
\hline & & no & 1829 & 81.8 & 1635 & 81.6 & 194 & 83.3 & \\
\hline \multirow[t]{2}{*}{6} & \multirow[t]{2}{*}{ The amount of food intake is small. } & yes & 355 & 15.9 & 323 & 16.1 & 32 & 13.7 & 0.346 \\
\hline & & no & 1882 & 84.1 & 1681 & 83.9 & 201 & 86.3 & \\
\hline \multirow[t]{2}{*}{7} & \multirow[t]{2}{*}{ His/her eats too fast to chew well. } & yes & 200 & 8.9 & 183 & 9.1 & 17 & 7.3 & 0.353 \\
\hline & & no & 2037 & 91.1 & 1821 & 90.9 & 216 & 92.7 & \\
\hline \multirow[t]{2}{*}{8} & \multirow[t]{2}{*}{ He/she stores the food in his/her mouth. } & yes & 139 & 6.2 & 124 & 6.2 & 15 & 6.4 & 0.881 \\
\hline & & no & 2098 & 93.8 & 1880 & 93.8 & 218 & 93.6 & \\
\hline \multirow[t]{2}{*}{9} & \multirow[t]{2}{*}{ He/she is not interested in eating. } & yes & 122 & 5.5 & 115 & 5.7 & 7 & 3.0 & 0.082 \\
\hline & & no & 2115 & 94.5 & 1889 & 94.3 & 226 & 97.0 & \\
\hline \multirow[t]{2}{*}{10} & \multirow[t]{2}{*}{ He/she eats too much. } & yes & 110 & 4.9 & 92 & 4.6 & 18 & 7.7 & 0.036 \\
\hline & & no & 2127 & 95.1 & 1912 & 95.4 & 215 & 92.3 & \\
\hline \multirow[t]{2}{*}{11} & He/she takes food out of his/her mouth. & yes & 95 & 4.2 & 86 & 4.3 & 9 & 3.9 & 0.759 \\
\hline & & no & 2142 & 95.8 & 1918 & 95.7 & 224 & 96.1 & \\
\hline
\end{tabular}

$\mathrm{p}: \mathrm{x}^{2}$ test

groups. The items are depicted in the order that each was identified as a parental concern. The item with the highest proportion of participants answering "yes" was "taking too much time to eat (slow eaters)" (33.1\%), followed by "picky eating (eating only certain foods)" (31.0\%), "inconsistent food intake" (25.0\%), "playing with food/utensils while eating" (23.8\%), "preferring sweetened beverages and snacks over meals" (18.2\%), "small food intake" (15.9\%), "eating too fast to chew well" (8.9\%), "not swallowing food" $(6.2 \%)$, "disinterested in foods" (5.5\%), "eating too much" (4.9\%), and "spitting out food" (4.2\%).

In the "not cooking together" group, the proportion of parents agreeing to the concern about their children "picky eating (eating only certain foods)" ( $p=0.034$ ) and "playing with food/utensils eating a meal while eating" ( $p=0.007)$ was higher, and "he/she eats too much" ( $p=$ $0.036)$ was lower, than in the "cooking together" group.

Table 4 shows the results of the associations between "parental concerns about the diets of the child" and "parent and child cooking together" using step-wise multivariate analysis. In Model 1, the analysis showed that three factors were associated with parent-child cooking together: not picky eating (odds ratio $[\mathrm{OR}]=$ 1.39; 95\% confidence interval $[\mathrm{CI}]=1.02-1.91 ; p=$ $0.039)$, not playing with food/utensils while eating ( $\mathrm{OR}=$ $1.59 ; 95 \% \mathrm{CI}=1.11-2.28 ; p=0.013)$, and not eating too much $(\mathrm{OR}=0.57 ; 95 \% \mathrm{CI}=0.34-0.97 ; p=0.040)$. In Model 2, the analysis also showed that the three factors were significantly associated with parent-child cooking together were not picky eating $(\mathrm{OR}=1.39 ; 95 \% \mathrm{CI}=$ 1.01-1.91; $p=0.041)$, not playing with food/utensils while eating $(\mathrm{OR}=1.56 ; 95 \% \mathrm{CI}=1.08-2.25 ; p=0.017)$, and not eating too much $(\mathrm{OR}=0.55 ; 95 \% \mathrm{CI}=0.32-$ $0.94 ; p=0.030$ ).

Table 5 shows the food intake frequency of children for both groups. In the "cooking together" group, the intake frequency of fish $(p=0.011)$, soybeans/soy products $(p=0.001)$, vegetables $(p=0.003)$, and milk $(p=0.002)$ was higher than that in the "not cooking together" group. On the other hand, the frequency of eating fast food was lower in the "cooking together" group than in 
Table 4 Associations between "parental concerns about the diets of the child" and "parent and child cooking together"

\begin{tabular}{|c|c|c|c|c|c|c|c|c|c|c|}
\hline \multirow{2}{*}{\multicolumn{3}{|c|}{$\begin{array}{l}\text { Parental concerns about the diets of the child } \\
\text { (Dependent variable) }\end{array}$}} & \multicolumn{8}{|c|}{ Child-parent cooking a meal together (Independent variable) } \\
\hline & & & \multicolumn{4}{|c|}{ Model 1} & \multicolumn{4}{|c|}{ Model 2} \\
\hline & & & \multirow{2}{*}{$\frac{\mathrm{OR}}{1.00}$} & \multicolumn{2}{|c|}{$95 \% \mathrm{Cl}$} & \multirow[t]{2}{*}{$\mathrm{p}$} & \multirow{2}{*}{$\frac{\mathrm{OR}}{1.00}$} & \multicolumn{2}{|l|}{$95 \% \mathrm{Cl}$} & \multirow[t]{2}{*}{$\mathrm{p}$} \\
\hline 1 & He/she takes too much time for eating (eats slowly). & yes & & & & & & & & \\
\hline & & no & 1.14 & 0.85 & 1.53 & 0.396 & 1.11 & 0.83 & 1.50 & 0.478 \\
\hline \multirow[t]{2}{*}{2} & $\mathrm{He} /$ she is a picky eater (eating only certain foods). & yes & 1.00 & & & & 1.00 & & & \\
\hline & & no & 1.39 & 1.02 & 1.91 & 0.039 & 1.39 & 1.01 & 1.91 & 0.041 \\
\hline \multirow[t]{2}{*}{3} & The amount of food intake is inconsistent (too much or too little, & yes & 1.00 & & & & 1.00 & & & \\
\hline & & no & 1.02 & 0.74 & 1.41 & 0.886 & 1.01 & 0.73 & 1.39 & 0.972 \\
\hline \multirow[t]{2}{*}{4} & $\mathrm{He} /$ she plays with food while eating. & yes & 1.00 & & & & 1.00 & & & \\
\hline & & no & 1.59 & 1.11 & 2.28 & 0.013 & 1.56 & 1.08 & 2.25 & 0.017 \\
\hline \multirow[t]{2}{*}{5} & $\mathrm{He} /$ she desires sweetened beverage or sweets more than a meal. & yes & 1.00 & & & & 1.00 & & & \\
\hline & & no & 1.13 & 0.79 & 1.63 & 0.499 & 1.13 & 0.78 & 1.64 & 0.513 \\
\hline \multirow[t]{2}{*}{6} & The amount of food intake is small. & yes & 1.00 & & & & 1.00 & & & \\
\hline & & no & 1.22 & 0.82 & 1.81 & 0.328 & 1.22 & 0.82 & 1.82 & 0.324 \\
\hline \multirow[t]{2}{*}{7} & His/her eats too fast to chew well. & yes & 1.00 & & & & 1.00 & & & \\
\hline & & no & 1.21 & 0.72 & 2.04 & 0.479 & 1.19 & 0.70 & 2.01 & 0.526 \\
\hline \multirow[t]{2}{*}{8} & He/she stores the food in his/her mouth. & yes & 1.00 & & & & 1.00 & & & \\
\hline & & no & 0.93 & 0.53 & 1.62 & 0.786 & 0.91 & 0.52 & 1.60 & 0.735 \\
\hline \multirow[t]{2}{*}{9} & $\mathrm{He} / \mathrm{she}$ is not interested in eating. & yes & 1.00 & & & & 1.00 & & & \\
\hline & & no & 1.86 & 0.85 & 4.05 & 0.120 & 1.71 & 0.78 & 3.75 & 0.178 \\
\hline \multirow[t]{2}{*}{10} & $\mathrm{He} / \mathrm{she}$ eats too much. & yes & 1.00 & & & & 1.00 & & & \\
\hline & & no & 0.57 & 0.34 & 0.97 & 0.040 & 0.55 & 0.32 & 0.94 & 0.030 \\
\hline \multirow[t]{2}{*}{11} & He/she takes food out of his/her mouth. & yes & 1.00 & & & & 1.00 & & & \\
\hline & & no & 1.07 & 0.53 & 2.16 & 0.855 & 0.94 & 0.46 & 1.92 & 0.859 \\
\hline
\end{tabular}

Model 1: adjusted relationship for the child, sex of child, employment status of mother, family living together

Model 2: adjusted relationship for the child, sex of child, employment status of mother, family living together, subjective economic status, leisure time, caregiver of the child during the day

OR Odds ratio, $\mathrm{Cl}$ Confidence interval

the "not cooking together" group $(p=0.014)$. Furthermore, the FDS was higher in the "cooking together" group than in the "not cooking together" group $(p=0.002)$.

\section{Discussion}

\section{Relationship between cooking meals together and} parental concerns about the dietary habits of children

In the "National nutrition survey on preschool children" conducted in Japan [5], the parental concerns about the eating behaviors of children included "picky eating" and "playing with food/utensils while eating. Our study results confirmed that parents and children cooking meals together was associated with a lack of concern about children "picky eating" or "playing with food/utensils while eating," but these parents were more likely to be concerned about children "eating too much" compared with parents who did not cook a meal together with their children. Thus, while in the conclusion we can speculate that cooking together may alleviate or increase the concerns of parents, this would have to be tested in interventional or experimental studies to explore it further.

The results of a previous systematic review highlighted the impact of parental involvement in dietary interventions to improve the dietary habits of children [12]. Family-based child nutrition programs are beneficial to all children irrespective of socioeconomic status $[11,12]$ and may be important to expand daily participation in meal preparation $[11,14,15]$.

A previous study reported that "cooking programs for parents and children through home visits for low income families" [11] and "responsible for child's cooking" could improve picky eating in a family intervention setting [13]. These findings were similar to those of the present study. However, relatively few studies included schoolaged children [12]. Hence, further research is needed.

Some studies conducted in other countries reported that picky eating was related to food intake [20]. A study 
Table 5 Frequency of food intake by the parent-child cooking together group

\begin{tabular}{|c|c|c|c|c|c|c|}
\hline \multirow[t]{3}{*}{ food category } & \multirow[t]{3}{*}{ frequency } & \multirow{2}{*}{\multicolumn{2}{|c|}{$\frac{\text { not cooking together }}{n=2004}$}} & \multirow{2}{*}{\multicolumn{2}{|c|}{$\begin{array}{l}\text { cooking together } \\
n=233\end{array}$}} & \multirow[t]{3}{*}{$p$} \\
\hline & & & & & & \\
\hline & & $\mathrm{n}$ & $\%$ & $n$ & $\%$ & \\
\hline \multicolumn{7}{|l|}{ Food group } \\
\hline \multirow[t]{6}{*}{ grain } & $\geq 2$ times per day & 1953 & 97.5 & 231 & 99.1 & 0.167 \\
\hline & Once a day & 35 & 1.8 & 1 & 0.4 & \\
\hline & 4-6 days /week & 12 & 0.6 & 1 & 0.4 & \\
\hline & 1-3 days /week & 2 & 0.1 & 0 & 0.0 & \\
\hline & less than once a week & 2 & 0.1 & 0 & 0.0 & \\
\hline & have not eaten yet & 0 & 0.0 & 0 & 0.0 & \\
\hline \multirow[t]{6}{*}{ fish } & $\geq 2$ times per day & 105 & 5.2 & 19 & 8.2 & 0.011 \\
\hline & Once a day & 230 & 11.5 & 33 & 14.2 & \\
\hline & 4-6 days /week & 466 & 23.3 & 56 & 24.0 & \\
\hline & 1-3 days /week & 1076 & 53.7 & 116 & 46.8 & \\
\hline & less than once a week & 125 & 6.2 & 8 & 3.4 & \\
\hline & have not eaten yet & 2 & 0.1 & 1 & 0.4 & \\
\hline \multirow[t]{6}{*}{ meat } & $\geq 2$ times per day & 245 & 12.2 & 41 & 17.6 & 0.140 \\
\hline & Once a day & 396 & 19.8 & 52 & 22.3 & \\
\hline & 4-6 days /week & 905 & 45.2 & 83 & 35.6 & \\
\hline & 1-3 days /week & 434 & 21.7 & 52 & 22.3 & \\
\hline & less than once a week & 23 & 1.2 & 3 & 1.3 & \\
\hline & have not eaten yet & 1 & 0.1 & 2 & 0.9 & \\
\hline \multirow[t]{6}{*}{ eggs } & $\geq 2$ times per day & 79 & 3.9 & 13 & 5.6 & 0.279 \\
\hline & Once a day & 436 & 21.8 & 64 & 27.5 & \\
\hline & 4-6 days /week & 708 & 35.3 & 76 & 32.6 & \\
\hline & 1-3 days /week & 604 & 30.1 & 63 & 27.0 & \\
\hline & less than once a week & 144 & 7.2 & 13 & 5.6 & \\
\hline & have not eaten yet & 33 & 1.7 & 4 & 1.7 & \\
\hline \multirow[t]{6}{*}{ soybeans and soy products } & $\geq 2$ times per day & 136 & 6.8 & 24 & 10.3 & 0.001 \\
\hline & Once a day & 411 & 20.5 & 53 & 22.8 & \\
\hline & 4-6 days /week & 616 & 30.7 & 74 & 31.8 & \\
\hline & 1-3 days /week & 701 & 35.0 & 65 & 27.9 & \\
\hline & less than once a week & 138 & 6.9 & 14 & 6.0 & \\
\hline & have not eaten yet & 2 & 0.1 & 3 & 1.3 & \\
\hline \multirow[t]{6}{*}{ vegetables } & $\geq 2$ times per day & 1064 & 53.1 & 143 & 61.4 & 0.003 \\
\hline & Once a day & 497 & 24.8 & 41 & 17.6 & \\
\hline & 4-6 days /week & 286 & 14.3 & 29 & 12.5 & \\
\hline & 1-3 days /week & 135 & 6.7 & 15 & 6.4 & \\
\hline & less than once a week & 21 & 1.1 & 3 & 1.3 & \\
\hline & have not eaten yet & 1 & 0.1 & 2 & 0.9 & \\
\hline \multirow[t]{5}{*}{ fruit } & $\geq 2$ times per day & 208 & 10.4 & 34 & 14.6 & 0.306 \\
\hline & Once a day & 555 & 27.7 & 60 & 25.8 & \\
\hline & 4-6 days /week & 543 & 27.1 & 66 & 28.3 & \\
\hline & 1-3 days /week & 531 & 26.5 & 51 & 21.9 & \\
\hline & less than once a week & 162 & 8.1 & 21 & 9.0 & \\
\hline
\end{tabular}


Table 5 Frequency of food intake by the parent-child cooking together group (Continued)

\begin{tabular}{|c|c|c|c|c|c|c|}
\hline \multirow[t]{3}{*}{ food category } & \multirow[t]{3}{*}{ frequency } & \multicolumn{2}{|c|}{ not cooking together } & \multicolumn{2}{|c|}{ cooking together } & \multirow[t]{3}{*}{$p$} \\
\hline & & \multicolumn{2}{|l|}{$n=2004$} & \multicolumn{2}{|c|}{$n=233$} & \\
\hline & & $\mathrm{n}$ & $\%$ & $\mathrm{n}$ & $\%$ & \\
\hline & have not eaten yet & 5 & 0.3 & 1 & 0.4 & \\
\hline \multirow[t]{6}{*}{ milk } & $\geq 2$ times per day & 706 & 35.2 & 103 & 44.2 & 0.002 \\
\hline & Once a day & 718 & 35.8 & 91 & 39.1 & \\
\hline & 4-6 days /week & 305 & 15.2 & 20 & 8.6 & \\
\hline & 1-3 days /week & 203 & 10.1 & 18 & 7.7 & \\
\hline & less than once a week & 52 & 2.6 & 1 & 0.4 & \\
\hline & have not eaten yet & 20 & 1.0 & 0 & 0.0 & \\
\hline \multicolumn{7}{|l|}{ Processed food } \\
\hline \multirow[t]{6}{*}{ sweetened beverage } & $\geq 2$ times per day & 206 & 10.3 & 28 & 12.0 & 0.814 \\
\hline & Once a day & 407 & 20.3 & 52 & 22.3 & \\
\hline & 4-6 days /week & 310 & 15.5 & 33 & 14.2 & \\
\hline & 1-3 days /week & 666 & 33.2 & 69 & 29.6 & \\
\hline & less than once a week & 371 & 18.5 & 46 & 19.7 & \\
\hline & have not eaten yet & 44 & 2.2 & 5 & 2.2 & \\
\hline \multirow[t]{6}{*}{ confectionery } & $\geq 2$ times per day & 241 & 12.0 & 33 & 14.2 & 0.481 \\
\hline & Once a day & 970 & 48.4 & 104 & 44.6 & \\
\hline & 4-6 days /week & 364 & 18.2 & 38 & 16.3 & \\
\hline & 1-3 days /week & 321 & 16.0 & 40 & 17.2 & \\
\hline & less than once a week & 97 & 4.8 & 17 & 7.3 & \\
\hline & have not eaten yet & 11 & 0.6 & 1 & 0.4 & \\
\hline \multirow[t]{6}{*}{ instant noodle } & $\geq 2$ times per day & 0 & 0.0 & 0 & 0.0 & 0.082 \\
\hline & Once a day & 4 & 0.2 & 1 & 0.4 & \\
\hline & 4-6 days /week & 13 & 0.7 & 2 & 0.9 & \\
\hline & 1-3 days /week & 187 & 9.3 & 23 & 9.9 & \\
\hline & less than once a week & 1451 & 72.4 & 150 & 64.4 & \\
\hline & have not eaten yet & 349 & 17.4 & 57 & 24.5 & \\
\hline \multirow[t]{7}{*}{ fast food } & $\geq 2$ times per day & 0 & 0.0 & 0 & 0.0 & 0.014 \\
\hline & Once a day & 5 & 0.3 & 1 & 0.4 & \\
\hline & 4-6 days /week & 15 & 0.8 & 3 & 1.3 & \\
\hline & 1-3 days /week & 232 & 11.6 & 17 & 7.3 & \\
\hline & less than once a week & 1642 & 81.9 & 188 & 80.7 & \\
\hline & have not eaten yet & 110 & 5.5 & 24 & 10.3 & \\
\hline & & Ismean & SE & Ismean & SE & \\
\hline Food diversity score & 8 points/day & 3.64 & 0.19 & 4.04 & 0.22 & 0.002 \\
\hline Processed food score $\dagger$ & 4 points/day & 0.57 & 0.08 & 0.61 & 0.09 & 0.474 \\
\hline \multicolumn{7}{|l|}{$p: x^{2}$ test } \\
\hline
\end{tabular}

conducted in Japan in 1998 reported that the nutritional education approach involving children and parents cooking together improved the dietary habits of children
[21]. Although later studies demonstrated increased motivation for food intake owing to the parent cooking together with school-aged children [22, 23], few studies 
addressed early childhood. Therefore, the results obtained from the analysis of our study are valuable.

An intervention study conducted in the United States reported that parent-child communication is benefited by preparing meals together because the children have the opportunity to ask their parents about the ingredients of healthy lunch recipes that are provided in school lunch programs [24]. Another study reported that liking of different foods of children was determined by foodrelated behaviors learned at a young age [25].

The health and development of children are influenced by conversations with parents during meal preparation $[26,27]$ and the child feeding practices of the parents [28], which may alleviate some parental concerns. In our study, the concerns of children were expressed from the perspective of the parents. For example, even if a parent cooks a balanced meal, the children sometimes may still refuse to eat. Consequently, the parents become concerned about the health of their children. In other words, the background of the parents' concern is not only the health of their children but also their attitude towards eating [29], which may be a problem related to parent-child communication [30]. Future studies are warranted to deeply analyze the attitudes and behaviors of parents and children regarding the diet quality of children [31].

In addition, cooking together was related to leisure time, but not subjective economic status, employment status of mother, or the place where the children spend their daytime. In other words, it seems that there are other determinants for cooking a meal together. The attempts of a parent to cook meals with their children may be related to whether the parent enjoys cooking. In previous studies, it was reported that those who enjoyed cooking possessed the requisite skills [32] and were less likely to use processed or pre-cooked foods [33]. In addition, some studies reported the need for education and support of cooking skills based on the socioeconomic status of the household [34]. Enjoying cooking may be important to encourage parents to cook together with their children [33].

\section{Relationship between cooking a meal together and the food intake of children}

The group of cooking together exhibited more frequent intake of fish, soy/soy products, vegetables, and milk, which were reported to have a low intake frequency in the "National nutrition survey on preschool children" in Japan [5].

Our study showed that parent-child cooking a meal together was related to adequate food intake, including tasting a diversity of foods. In a study by Allirot X et al., it was showed that involving children in cooking can increase their willingness to taste novel foods and direct food choices towards foods containing vegetables [35]. Previous studies reported that providing early education in the place where the children spent their days, such as nursery school, kindergarten, etc., was effective in decreasing the intake of an unbalanced diet $[35,36]$. Our study identified that parent-child cooking a meal together at home could be important for healthy food intake by children.

In Health Japan 21 (second edition), the health of the next-generation incorporated indicators of eating behavior, such as "eating three meals a day" and "eating together," but there was no indicator of behaviors related to meal preparation [36]. To encourage healthy development in early childhood, it is important to improve not only the eating behavior but also the ability to cook meals $[10,37]$. Based on the results of our study, interventions to support parent-child cooking a meal together may be effective. Furthermore, it may also be vital to collaborate with the community and plan educational strategies to improve the cooking capabilities of both children and their parents [38, 39].

In the present study, parent-child cooking together was related to dietary habits of children and food intake, but the behavioral factors of parents related to the eating behaviors of children were not analyzed. Further studies on the relationship between parental behaviors, dietary concerns of the child, and food intake of the child are warranted.

There were several limitations to this study that should be addressed. First, the response rate was only $56.8 \%$. Hence, we relied on the 2015 database of the National nutrition survey on preschool children conducted by the MHLW. In this investigation, 3871 questionnaires were collected from 3936 children. However, only 2237 participants responded to all of the required items. The most unanswered items were height, weight, and subjective economic status. Although height and weight are measurable, it may have been difficult for some parents to subjectively gauge their economic status. Since this survey is conducted every 10 years, it is necessary to devise a method to increase the response rate for such items in future surveys. Second, it is unknown whether the parental concerns about the dietary habits of children are related to childhood development. Furthermore, children may help with cooking because of the lack of motivation of the parents. Therefore, further research is required [6, 11]. Third, items related to the dietary habits of the parents were limited. Despite these limitations, parental concerns about the dietary habits of children may be related to cooking a meal together with young children.

\section{Conclusions}

Cooking a meal together with a child may be related to the parent's lower concerns about the dietary habits of the child, including "picky eating" and "playing with food/utensils while eating," but may also be related to the higher concerns of "eating too much." 


\section{Additional file}

Additional file 1: Study population and procedure diagram of this study. (PDF $150 \mathrm{~kb}$ )

\section{Abbreviations}

$\mathrm{Cl}$ : Confidence interval; Lsmeans: Least squares mean; $\mathrm{MCH}$ : Maternal and child health; MHLW: Ministry of Health, Labour and Welfare; OR: Odds ratio; SD: Standard deviation; SE: Standard Error

\section{Acknowledgments}

No applicable.

\section{Authors' contributions}

Conceptualization: MI, KE, MM. Data curation: MI. Formal analysis: MI. Funding acquisition: MI. Methodology: MI, TY. Supervision: NY. Validation: MI, TY. Writing - original draft: MI, KE, MM. Writing - review \& editing: MH, TY, NY All authors read and approved the final manuscript.

\section{Funding}

This study was funded by a Health and Labour Sciences Research Grant in 2018 for the "Development of a food, nutrition, and dietary guide for healthy development in early childhood" (H29 Sukoyaka ippan 003 to MI). The funders had no role in study design, data collection/analysis, decision to publish, or preparation of the manuscript.

\section{Availability of data and materials}

Permission for the use of the dataset in the current study was obtained from the MHLW, Japan. All data belong to the MHLW and the database cannot be used for other studies.

\section{Ethics approval and consent to participate}

The study protocol was approved by the Ethics Committee of the National Institute of Public Health, Wako, Saitama, Japan (NIPH-TRN\#12021, February 1 , 2018).

\section{Consent for publication}

Not applicable.

\section{Competing interests}

The authors declare that they have no competing interests.

\section{Author details}

'Department of Health Promotion, National Institute of Public Health, 2-3-6 Minami, Wako, Saitama 351-0197, Japan. ${ }^{2}$ Faculty of Nutrition, Kagawa Nutrition University, 3-9-21 Chiyoda, Sakado, Saitama 350-0288, Japan. ${ }^{3}$ Department of Nutrition, Faculty of Health Sciences, Aomori University of Health and Welfare, 58-1 Mase, Hamadate, Aomori 030-8505, Japan. ${ }^{4}$ Department of Child Studies, Faculty of Child Studies, Seitoku University, 550 Iwase, Matsudo, Chiba 271-8555, Japan.

\section{Received: 2 April 2019 Accepted: 30 August 2019} Published online: 18 November 2019

\section{References}

1. WHO. Meeting the challenge of a new era for achieving healthy diet and nutrition. Outcomes of the 2nd global nutrition policy review. 2018. http:// www.who.int/nutrition/events/2016 side-event-outcome-2ndglobalnutritionpolicyreview-2dec/en/. Accessed 3 Apr 2019.

2. Nishida C. Preliminary results of the $2^{\text {nd }}$ global nutrition policy review: a global perspective. Meeting the challenge of a new era for achieving healthy diet and nutrition. Outcomes of the 2 nd global nutrition policy review. 2018. http://www.who.int/nutrition/events/2016_side-eventpresentation-Nishida-preliminaryresults-2ndGNPR.pdf?ua=1. Accessed 3 Apr 2019.

3. Darton $\mathrm{H}$, Nishida C, James WPT. A life course approach to diet, nutrition and prevention of chronic diseases. Public Health Nutr. 2004;7:101-21.

4. Herman DR, Baer MT, Adams E, Cunninham-Sabo L, Duran N, Johnson DB, Yakes E. Life course perspective: evidence for the role of nutrition. Matern Child Health J. 2014;18:450-61.
5. Ministry of Health, Labour and Welfare (MHLW). Report on national nutrition survey on preschool children. 2016 (in Japanese). https://www.mhlw.go.jp/ stf/seisakunitsuite/bunya/0000134208.html Accessed 3 Apr 2019.

6. DeCosta P, Møller P, Frøst MB, Olsen A. Changing children's eating behaviour - a review of experimental research. Appetite. 2017;113:327-57. https://doi.org/10.1016/j.appet.2017.03.004.

7. Jarpe-Ratner E, Folkens S, Sharma S, Daro D, Edens NK. An experiential cooking and nutrition education program increase cooking self-efficacy and vegetable consumption in children and grades 3-8. J Nutr Educ Behav. 2016;48:697-705.

8. Nozue M, Ishida H, Hazano S, Nakanishi A, Yamamoto T, Abe A, Nishi N, Yokoyama T, Murayama N. Associations between Japanese schoolchildren's involvement in at-home meal preparation, their food intakes, and cooking skills. Nutr Res Prac. 2016;10:359-63.

9. Ministry of Agriculture, Forestry and Fisheries. Shokuiku promotion in school, nursery school, etc. White paper on Shokuiku, Shokuiku promotion policies; FY. 2015. p. 35. (in Japanese).

10. Mikkelsen MV, Husby S, Skov LR, Perez-Cueto F. A systematic review of types of healthy eating interventions in preschools. Nutr J. 2014;13:56.

11. Izumi BT, Eckhardt CL, Wilson DP, Cahill J. A cooking intervention to increase vegetable consumption by parents with children enrolled in an early head start home visiting program: a pilot study in Portland, Oregon, 2013-2014. Prev Chronic Dis. 2016;13:E174. https://doi.org/10.5888/pcd13. 160259

12. Black AP, D'Onise $K$, McDermott R, Vally H, O'Dea K. How effective are family-based and institutional nutrition interventions in improving children's diet and health? A systematic review. BMC Public Health. 2017;17:818. https://doi.org/10.1186/s12889-017-4795-5.

13. Sobko T, Jia Z, Kaplan M, Lee A, Tseng CH. Promoting healthy eating and active playtime by connecting to nature families with preschool children: evaluation of pilot study "Play\&Grow". Pediatr Res. 2017;81:572-81. https:// doi.org/10.1038/pr.2016.251.

14. Litterbach EV, Campbell K, Spence A. Family meals with young children: an online study of family mealtime characteristics, among Australian families with children aged six months to six years. BMC Public Health. 2017;17:111.

15. Synnott K, Bogue J, Edwards CA, Scott JA, Higgins S, Norin E, Frias D, Amarri S, Adam R. Parental perceptions of feeding practices in five European countries: an exploratory study. Eur J Clin Nutr. 2007;61:946-56 http://www. maff.go.jp/j/syokuiku/wpaper/pdf/gaiyou_all.pdf. Accessed 21 Dec 2018.

16. Food and Agriculture Organization (FAO). Guidelines for measuring household and individual dietary diversity: FAO; 2013. http://www.fao.org/3/ a-i1983e.pdf

17. The Japanese Society for Pediatric Endocrinology. Assessment of physical status for Japanese infants and children. (in Japanese) http://jspe.umin.jp/ jspe_test/medical/taikaku.html. Accessed 10 Sept 2019.

18. Kato N, Takimoto H, Yokoyama T. Technical report for Japanese national growth survey for infants and children in 2010. In: Report of a study on statistical analyses, methods, and utilization of Japanese national growth survey for infants and children; 2012. p. 111-43. https://www.niph.go.jp/ soshiki/07shougai/hatsuiku/houkoku120617.pdf.

19. Study team on statistical analysis of assessment of physical growth in Japanese children, Ministry of Health, Labour and Welfare (MHLW). A manual for the assessment of physical growth in Japanese children. Tokyo: MHLW; 2012. p. 48. (in Japanese)

20. Samuel TM, Musa-Veloso K, Ho M, Venditti C, Shahkhalili-Dulloo Y. A narrative review of childhood picky eating and its relationship to food intakes, nutritional status, and growth. Nutrients. 2018;10. https://doi.org/10. 3390/nu10121992.

21. Yamaguchi S, Haruki T, Harada A. The correlation with mother's eating habits to dietary education of their preschool children. Jpn J Nutr. 1996:54:87-96.

22. Vedanthan R, Bansilal S, Soto AV, Kovacic JC, Latina J, Jaslow R, Santana M, Gorga E, Kasarskis A, Hajjar R, Schadt EE, Björkegren JL, Fayad ZA, Fuster V. Family-based approaches to cardiovascular health promotion. J Am Coll Cardiol. 2016;67(14):1725-37.

23. van der Horst $K$, Ferrage A, Rytz A. Involving children in meal preparation. Effects on food intake. Appetite. 2014;79:18-24.

24. Sharma SV, Rashid T, Ranjit N, Byrd-Williams C, Chuang RJ, Roberts-Gray C, Briley M, Sweitzer S, Hoelscher DM. Effectiveness of the lunch is in the bag program on communication between the parent, child and child-care provider around fruits, vegetables and whole grain foods: a grouprandomized controlled trial. Prev Med. 2015;81:1-8. 
25. Yuan WL, Rigal N, Monnery-Patris S, Chabanet C, Forhan A, Charles MA, de Lauzon-Guillain B, on behalf of the EDEN mother-child cohort Study Group. Early determinants of food liking among 5y-old children: a longitudinal study from the EDEN mother-child cohort. Int J Behav Nutr Phys Act. 2016;13:20.

26. Eto K, Nakanishi A, Takemi Y. Associations between family dinner frequency and voluntary mealtime communication with dietary attitudes, dietary behaviors, and quality of life: a cross-sectional and longitudinal study of 5th and 8th grade students. Jpn J Nutr Diet. 2014;72:113-25.

27. Hersch D, Perdue L, Ambroz T, Boucher JL. The impact of cooking classes on food related preferences, attitudes, and behaviors of school-aged children: a systematic review of the evidence, 2003-2014. Prev Chronic Dis. 2014;11:140267.

28. Savage JS, Hohman EE, Marini ME, Shelly A, Paul LM, Birch LL. INSIGHT responsive parenting intervention and infant feeding practices: randomized clinical trial. Int J Behav Nutr Phys Act. 2018:15:64.

29. McMartin SE, Willows ND, Colman I, Ohinmaa A, Storey K, Veugelers PJ. Diet quality and feelings of worry, sadness or unhappiness in Canadian children. Can J Public Health. 2013;104:e322-6.

30. Ainuki T, Eto K. Associations of family meal practices with health status and dietary intake: a literature review using Japanese journal databases. JJHEP. 2015;23:279-89 (In Japanese).

31. Farrow CV, Coulthard H. Relationships between sensory sensitivity, anxiety and selective eating in children. Appetite. 2012;58:842-6.

32. Méjean C, Si Hassen W, Gojard S, Ducrot P, Lampuré A, Brug H, Lien N, Nicolaou M, Holdsworth M, Terragni L, Hercberg S, Castetbon K. Social disparities in food preparation behaviours: a DEDIPAC study. Nutr J. 2017:16:62.

33. Wolfson JA, Smith KC, Frattaroli S, Bleich SN. Public perceptions of cooking and the implications for cooking behaviour in the USA. Public Health Nutr. 2016;19:1606-15.

34. Taillie LS. Who's cooking? Trends in US home food preparation by gender, education, and race/ethnicity from 2003 to 2016. Nutr J. 2018;17:41.

35. Allirot X, da Quinta N, Chokupermal K, Urdaneta E. Involving children in cooking activities: a potential strategy for directing food choices toward novel foods containing vegetables. Appetite. 2016;103:275-85.

36. Children's Health. Targets for maintenance and improvement of functions necessary for engaging in social life. Health Japan 21 (the second term) http://www.nibiohn.go.jp/eiken/kenkounippon21/en/kenkounippon21/ mokuhyou03.html. Accessed 21 Dec 2018.

37. Black MM, Walker SP, Fernand LC, Andersen CT, DiGiolamo AM, et al. Early childhood development coming of age: through the life course. Lancet. 2017;389:77-90.

38. Ishikawa M, Eto K, Haraikawa M, Sasaki K, Yamagata Z, Yokoyama T, Kato N, Morinaga Y, Yamazaki Y. Multi-professional meetings on health checks and communication in providing nutritional guidance for infants and toddlers in Japan: a cross-sectional, national survey-based study. BMC Pediat. 2018;18:325

39. Spence AC, Campbell KJ, Crawford DA, McNaughton SA, Hesketh KD. Mediators of improved child diet quality following a health promotion intervention; the Melbourne infant program. Int J Behav Nutr Phys Act. 2014;11:137

\section{Publisher's Note}

Springer Nature remains neutral with regard to jurisdictional claims in published maps and institutional affiliations.

Ready to submit your research? Choose BMC and benefit from:

- fast, convenient online submission

- thorough peer review by experienced researchers in your field

- rapid publication on acceptance

- support for research data, including large and complex data types

- gold Open Access which fosters wider collaboration and increased citations

- maximum visibility for your research: over $100 \mathrm{M}$ website views per year

At BMC, research is always in progress.

Learn more biomedcentral.com/submissions 